\title{
Müzik Öğretmenliği Lisans Programında Yer Alan Piyano Eğitimi Dersine Yönelik Öğretim Elemanı ve Öğrenci Beklentileri*
}

\author{
Expectations of Instructors and Students for Piano Education Course in Music \\ Teaching Undergraduate Program
}

\section{Eren Lehimler}

Dr. Arş. Gör., Atatürk Üniversitesi Kazım Karabekir Eğitim Fakültesi Müzik Eğitimi Anabilim Dalı email: eren.lehimler@atauni.edu.tr (DORCID ID: https://orcid.org/0000-0003-0069-4797

\section{Kamil Onur Karatas}

Arş. Gör., Atatürk Üniversitesi Kazım Karabekir Eğitim Fakültesi Müzik Eğitimi Anabilim Dalı email: kamil.karatas@atauni.edu.tr (DORCID ID: https://orcid.org/0000-0002-7092-0182

* Bu çalışma "1. Uluslararası Sanad Congress (12-14 Aralık 2019)" sempozyumunda sunulan "Müzik Eğitimi Anabilim Dalı Müfredatında Yer Alan Piyano Eğitimi Dersine Yönelik Öğretim Elemanı ve Öğrenci Beklentileri” başlıklı bildiriden türetilmiştir.

iThenticate" iTu makale bilimsel etik ve kurallara uygun hazırlanmış ve intihal incelemesinden geçirilmiştir.

Atıf (APA 6)/To cite this article

Lehimler, E., \& Karataş, K. O. (2020). Müzik öğretmenliği lisans programında yer alan piyano eğitimi dersine yönelik öğretim elemanı ve öğrenci beklentileri. Atatürk Üniversitesi Güzel Sanatlar Enstitüsü Dergisi, 26(Müzik Özel Say1s1), 353-365. doi: https://doi.org/10.35247/ataunigsed.661021

Makale Gönderim Tarihi/Received: 18/12/2019

Makale Kabul Tarihi/Accepted: 18/02/2020

Makale Yayın Tarihi/Published: 25/03/2020

Research Article / Araștırma Makalesi

\section{$\ddot{O} z$}

Araştırmada, müzik öğretmenliği lisans programında yer alan piyano eğitimi dersini alan öğrencilerin ve bu dersi yürüten öğretim elemanlarının beklentilerini ortaya koymak amaçlanmıştır. Belirlenen amaç doğrultusunda, 3 farklı müzik eğitimi anabilim dalında öğrenim gören ve piyano eğitimi derslerini alan ögrenciler ve bu anabilim dallarında görev yapıp, piyano eğitimi derslerini yürüten öğretim elemanları ile çalışma gerçekleștirilmiștir.

Araştırmada, tarama modeli kullanılmış ve veriler modele uygun olarak görüșme tekniği ile elde edilmiștir. Veriler, içerik analizi ve yüzde-frekans olarak değerlendirilmiştir. Değerlendirme aşamasında, öğrenci ve öğretim elemanlarının beklentileri ortaya konulmuş, elde edilen veriler ıșığında iki grubun beklentileri birbirleri ile karşılaştırılmıştır.

Sonuç olarak çalıșmanın, piyano eğitimi dersine yönelik elde edilen beklentiler ıșı ğında ortak bir kalite gelișimi sağlanabilirliği açısından önem taşıdığı ve piyano eğitimi dersinin kalitesini artırmak için yol gösterici olduğu düșünülmektedir.

Anahtar Kelimeler: Müzik Eğitimi, Piyano Eğitimi, Beklenti.

\begin{abstract}
In this research, it is aimed to reveal the expectations of the students who take piano education course in the curriculum of music education and of the instructors who carry out this course. In accordance with this aim, the research carried out with the students working in 3 different music education departments and taking piano education courses and with the instructors who work in these departments and conduct piano education courses.

In the research, general survey model used and data obtained by interview technique in accordance with the model. Data evaluated as content analysis and percentage-frequency. In the evaluation phase, the expectations of students and instructors revealed and the expectations of the two groups compared with each other in the light of the data obtained.

As a result, it is considered that the study is important in terms of achieving a common quality improvement and guiding to improve the quality of the piano education course in the light of the expectations to be obtained for the piano education course.
\end{abstract}

Keywords: Music Education, Piano Education, Expectation

\section{Giriş}

"Birçok alanda süregiden rekabette önemli bir unsur haline gelen kalite kavramı "kalite, müşterinin istediğidir" biçiminde tanımlanmaya başlandığından bu yana üniversiteler hizmetlerinin ve ürünlerinin alıcısı ya da yararlanıcısı konumunda olan grupları daha çok dikkate alır duruma gelmişlerdir. Bu gruplardan biri de üniversitelerin hâlihazırdaki ve gelecekteki öğrencileridir. Eğitim hizmetlerinin alıcısı konumundaki öğrencilerin daha kaliteli eğitim veren üniversiteleri tercih edecekleri varsayılmaktadır. Bunun nedeni kaliteli eğitim hizmeti veren üniversitelerin, mezunlarının nitelikleri ile iş piyasası arasında ussal bir denge kurmaları ve bunun sonucunda da bu okulların mezunlarının daha kolay istihdam edilebilmeleridir" (Ekinci ve Burgaz, 2007'den aktaran Saydan, 2008). Kalite kavramının akademilerde yer bulmasının sonucu olarak ortaya çıkan "eğitimde akreditasyon" süreci uygulanmaya başlanmıştır. Kurulan çeşitli akreditasyon derneklerinin Yükseköğretim 
Kurumu ile yaptığı protokollerle üniversitelerimizin bölümleri akredite olmaya başlamış ve akredite olan bölümler üniversite tercih listelerinde "akredite olmuştur" ibaresi ile yer almaya başlamıştır.

Eğitimde akredite olma sürecine bakıldığında, kalitenin artırılmasında tüm bileşenler gözden geçirilmelidir. Bileşenler arasından ilk olarak insanoğlunun süreç içerisindeki durumunun ortaya konulması gerektiği düşünülmektedir.

İnsanoğlunun farklı her bir davranışının temelindeki “neden“ bir amaca yöneliktir. Bu amaçlar bütünü içerisinde yer alan eğitim sürecinde de insanoğlunun farklı güdüleri, beklentileri ve tutumları vardır. Bu sebeple eğitim sürecinin ortaya konulması söz konusu olduğunda öğrencilerin-eğitimcilerin davranışları ve motivasyonlarının bu süreç içerisinde göz ardı edilmemesi gerektiği düşünülmektedir.

Yapılan araştırmada da, ülkemizde Eğitim Fakülteleri bünyesinde öğretim programını yürüten Müzik Eğitimi Anabilim Dallarının lisans programlarında yer alan Piyano Ĕ̆itimi dersinin mevcut durumu, dersi yürüten öğretim elemanlarının ve dersi alan öğrencilerin -piyano eğitimi sürecinde bulunan varlığın insan olduğu düşünülerekgeçen süreç içerisindeki davranışları ve motivasyonlarının nasıl olduğu ele alınarak açıklanmaya çalışılmıştır.

Eğitim sürecinin sonucunda ortaya konacak olan çıktılara ulaşılması için motive olma durumu büyük önem taşımaktadır. Söz konusu motivasyon; beklenti, güdü ve ödül kavramları ile açıklanabilir. Motivasyon sürecinin işlemesinde ise davranışlar devreye girdiği için süreç içerisindeki tutum, istek ve çaba motivasyonu etkileyen faktörler olarak karşımıza çıkmaktadır.

Hem eğitimcinin hem de öğrencinin birbirlerine karşı olan davranışları eğitim sürecini etkilediğinden, motivasyon ve davranışlarının bir bütünlük içerisinde olası gerekmektedir.

Motivasyon sürecinin temel elemanları (1) ihtiyaçlar veya beklentiler, (2) davranış, (3) hedefler, (4) geri beslemenin bazı formlarıdır. Bu temel elemanların ilişkilendirilmesi şematik olarak şöyledir (Steers ve Porter, 1987'den aktaran Anık, 2007):

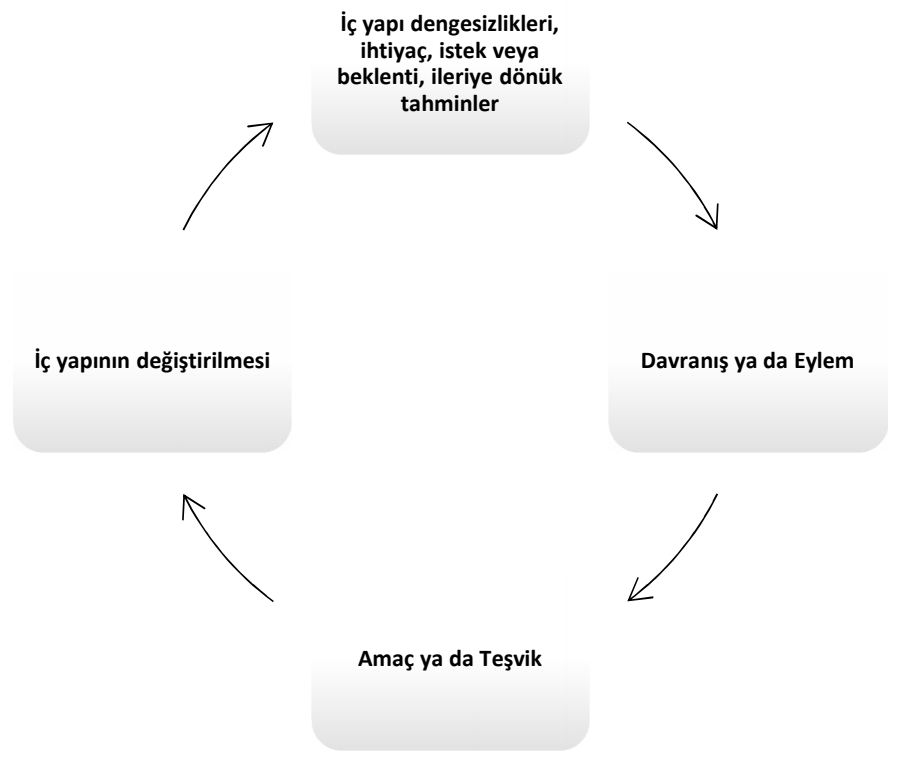

Şekil 1. Motivasyon süreci

Motivasyon sürecinin temel elemanları göz önüne alındığında şöyle bir kavramsal düzenek ortaya çıkmaktadır. Öncelikle, bireyin davranışına kaynaklık eden ve birbirleriyle etkileşim içindeki gerilim ve itici güç kavramlarını dikkate almak gerekmektedir. Ikinci olarak, bireyin iletişim/etkileşim ağ kurduğu ve geri besleme sağladiğ çevresel ortam faktörleri gündeme gelmektedir. Üçüncü olarak da, bireyin davranışının amacına yönelik olarak bir hedefinin bulunmasıdır (Anık, 2007).

Süreç teorileri adı altında toplanan motivasyon teorilerinin ağırlık noktası, kişilerin hangi amaçlar tarafından ve nasıl motive edildikleriyle ilgilidir. Motivasyona ilişkin süreç teorileri olarak Klasik Şartlanma, Beklenti Kuramı, Eşitlik ve Amaç Teorisidir (Erdem, 1998).

Klasik Şartlanmanın temelinde kişinin davranışlarına göre karşılaştığı sonuçlardır. Kişi karşılaştığı sonuca göre davranışını tekrarlayacak ya da tekrarlamayacaktır. Bu sebeple, Klasik Şartlanmanın en önemli elemanı ödüllendirme veya cezalandırmadır. Ödüllendirme ve cezalandırmada iki farklı şekilde olabilir. Birincisi maddi diğeri ise manevidir. Klasik şartlanma süreç olarak ilerler ve bu süreç aşağıdaki şekilde ifade edilebilir (Erdem, 
1998):

\title{
Davranış \\ Karşılaşılan Sonuç \\ Ödül veya Ceza
}

Şekil 2. Klasik şartlanma süreci

Motivasyon süreci içerisinde anılan bir diğer kavram olan "Beklenti”, hangi eylemin hangi sonuca yol açacağına ilişkin beslenen inançtır (Hampton, Summer, Webber, 1982'den aktaran Çevik, Perkmen ve Alkan, 2012).

"Değer Beklenti kuramlarının içinde en etkili olanı, Vroom tarafından formüle edilmiştir (Pinder, 1987). Kendinden öncekilerden yola çıkılarak geliştirilmiş olan bu kuram, geniş kabul görmüş, daha sonra Porter ve Lawler tarafından genişletilmiş, ayrıntılı bir model haline getirilmiştir (Davis 1984).” (aktaran Anık, 2007).

\begin{abstract}
Akat (1994) Vroom'un beklenti kuramını, "bir insanın güdülenmesi, belli bir davranışın amaca ulaştıracağı beklentisiyle, o bireyin amaca verdiği önemin çarpımına eşittir” şeklinde açıklamıştır (aktaran. Erdem, 1998). "Önermeye göre bir davranış ortaya koyma isteğinin derecesi, bu davranış ile amaçlanan sonucun başarılıp başarılamayacağına ilişkin inanç veya beklenti derecesi ile elde edilmek istenen sonucun birey için değeri, çekiciliği, algılanan subjektif önemi arasındaki etkileşime bağlı olarak artacak ya da azalacaktır (Küçükkurt 1988). Vroom da bu önerme çerçevesinde, bireyin alternatif davranışlar arasında yaptığ seçimi açıklayabilmek için bir model geliştirmiştir (Dereli, 1981). Vroom; (1964) bireyin tercihini belirleyen, varmak istediği sonucun veya hedefin zihinde takdir edilen düzeyini açıklayan kavramlardan 'valance'1 kullanmaktadır. Vroom (1964) Bireyin alternatif davranışlardan birini seçmesini bir dizi psikolojik olaya dayandırmıştır (aktaran Anık, 2007).
\end{abstract}

Bir diğer motivasyon süreci elemanlarından olan "Eşitlik Teorisi", bireyin kendisini aynı ortam içerisinde başkaları ile karşılaştırması temeline dayanan ve J. S. Adams tarafından geliştirilerek ortaya konan teoridir. Birey eğitim yaşantısı, iş yaşantısı, sosyal hayat, aile yaşantısı vb. ortamlarda herhangi bir konuda gösterdiği çabayı ve elde ettiği sonuçları aynı ortam içerisindeki farklı elemanların gösterdiği gayret ve elde ettikleri sonuçlar ile karşılaştırır. Karşılaştırmayı oranlama üzerinden yapar. Yaptığı oranların sonucunda eşitliğin olup olmadığı kanısina varir.

Motivasyon süreci içerisinde yer alan bir diğer kavram ise "Amaç Teorisi” dir. Edwin Locke tarafindan geliştirilen bu teoriye göre kişilerin belirlediği amaçlar onların motivasyon derecelerini de belirleyecektir. Amacın zorluğu ve özelliği; amacın kabulü ve amaca adanmışlık, amaca yönelik çabayı ve motivasyon düzeyini belirliyor. Zor ve spesifik amaçlarda performans daha yüksektir. Bu nedenle zor ve spesifik amaçlara sahip olan insanlar kolay ve genel amaçlara sahip olan insanlara göre daha yüksek performans gösterecektir. Amaçların kabulü ve amaca adanmak amacın zorluğu ve özelliği gibi amaca yönelik çabayı etkiler (Erdem, 1998).

Motivasyon süreci içerisinde yer alan ve yukarıda açıklamaları verilen tüm elemanlar bir bütün olarak ele alınarak, motivasyon terimi yerine "Beklenti Kuramı" olarak literatürde kullanılmaya başlanmıştır. Beklenti kuramı içerisinde amaç, davranış, çaba, sonuç vb. terimler bir araya toplanarak birleşik bir şekilde beklentiler incelendiği söylenebilir.

\section{Yöntem}

Araştırma piyano eğitimi sürecine ilişkin bir durum tespiti olduğundan dolayı tarama modeli içerisinde betimlenmiştir. Piyano Eğitimi dersini yürüten öğretim elemanları ve öğrenciler için aynı soruları kapsayan iki ayrı form oluşturulmuş ve veriler bu formlar ile elde edilmiştir.

Verilerin elde edilmesi için hazırlanan form 2 bölümden oluşmaktadır. Formun birinci bölümünde 1 puan en düşük, 5 puan en yüksek olacak şekilde derecelendirilen on bir soru bulunmaktadır. Formun ikinci bölümünde ise 5 sorudan oluşan yapılandırılmış görüşme formu bulunmaktadır. Hazırlanan derecelendirme ölçeği ve görüşme formları derse hazırbulunuşluk, tutum/davranış, amaç/önem ve değerlendirme/geri bildirim süreçlerini kapsamaktadır. Uygulanan form alanında uzman 3 öğretim üyesinin görüşleri doğrultusunda düzenlenmiştir.

Veriler üç üniversitenin (Atatürk Üniversitesi, İnönü Üniversitesi ve Ağr1 İbrahim Çeçen Üniversitesi) müzik eğitimi anabilim dalı bölümü birinci sınıf öğrencilerine $(n=79)$ ve piyano eğitimi dersini yürüten öğretim elemanlarına $(n=7)$ uygulanmıştır. Araştırma, evren örneklem tayinine gidilmeyerek çalışma grubu üzerinden yapılmış ve piyano dersine ilişkin öngörü, veriler ile açıklanmaya çalışılmıştır.

Formun birinci bölümünden elde edilen veriler yüzde/frekans olarak sunulmuştur. İkinci bölümde yer alan yapılandırılmış görüşme formunda ise verilen cevaplar kodlanmış ve kodlamalar yüzde/frekans olarak tablolar halinde sunulmuştur. 


\section{Bulgular}

Bu bölümde, bulgular formun bölümleri bazında genel ve ayrı ayrı sorulardan elde edilen verileri yüzde/frekans olarak verilmiștir.

\subsection{Derecelendirme ölçeği bulguları}

Hazırlanan derecelendirme ölçeğine öğrenciler tarafından verilen cevaplara göre ölçüm yapılan gruplar arası farklılığın olup olmadığı Anova ve Post-Hoc testleri ile ölçülmüş ve gruplar arasında anlamlı bir farklılığın olmadıği görülmüştür $(p=, 126)$

Tablo 1

Gruplar arası farklılaşmayı betimleyici Anova tablosu

\begin{tabular}{|c|c|c|c|c|c|c|c|c|c|c|}
\hline & \multicolumn{4}{|c|}{$f, x$ ve ss Değgerleri } & \multicolumn{6}{|c|}{ Anova Sonuçları } \\
\hline Puan & Grup & $\mathbf{N}$ & $\mathrm{X}$ & sS & Var. K & KT & Sd & KO & $\mathbf{F}$ & $p$ \\
\hline \multirow{6}{*}{$\begin{array}{l}\text { Derecelendirme } \\
\text { Ölçeği }\end{array}$} & Ağr1 & & & & & & & & \multirow{6}{*}{2,131} & \multirow{6}{*}{, 126} \\
\hline & $\begin{array}{l}\text { İbrahim } \\
\text { Cecen }\end{array}$ & 27 & 41,89 & 7,668 & G.Arası & 257,878 & 2 & 128,939 & & \\
\hline & Üni. & & & & & & & & & \\
\hline & İnönü Üni. & 21 & 42,67 & 7,337 & G.İçi & 4598,882 & 76 & 60,512 & & \\
\hline & $\begin{array}{c}\text { Atatürk } \\
\text { Üni. }\end{array}$ & 31 & 38,58 & 8,152 & \multirow[t]{2}{*}{ Toplam } & \multirow[t]{2}{*}{4856,759} & \multirow[t]{2}{*}{78} & & & \\
\hline & Toplam & 79 & 40,80 & 7,891 & & & & & & \\
\hline
\end{tabular}

“Piyano eğitimi dersine ne kadar çalışırsınız? - Öğrencilerinizin piyano ĕ̆itimi dersine çalışma durumları ne düzeydedir?" soruları ile öğrencilerden çalışma sürelerine yönelik kendi öz değerlendirmelerini yapmaları ve eğitimcilerin öğrencilerinin çalışma durumlarını derecelendirmeleri istenilmiştir. Yapılan değerlendirme sonucunda öğrencilerin derse "orta düzeyde" çalıştıkları bulgusuna ulaşılmıştır. Elde edilen veriler Tablo 2'de sunulmuştur.

Tablo 2

"Piyano eğitimi dersine ne kadar çalışırsınız? - Öğrencilerinizin piyano eğitimi dersine çalışma durumları ne düzeydedir?" sorularına yönelik betimleyici tablo

\begin{tabular}{|c|c|c|c|c|c|}
\hline \multicolumn{3}{|c|}{ Öğrenci Derecelendirmesi } & \multicolumn{3}{|c|}{ Eğitimci Değerlendirmesi } \\
\hline Derecelendirme Puanı & Frekans & Yüzde & Yüzde & Frekans & Derecelendirme Puanı \\
\hline 1 & 4 & 5,1 & 0,0 & 0 & 1 \\
\hline 2 & 19 & 24,1 & 14,3 & 1 & 2 \\
\hline 3 & 27 & 34,2 & 85,7 & 6 & 3 \\
\hline 4 & 17 & 21,5 & 0,0 & 0 & 4 \\
\hline 5 & 12 & 15,2 & 0,0 & 0 & 5 \\
\hline Toplam & 79 & 100 & 100 & 7 & Toplam \\
\hline
\end{tabular}

“Piyano eğitimi dersi başarınıza yönelik öngörünüz ne düzeydedir? - Öğrencilerinizin piyano ĕğitimi dersi başarılarına yönelik öngörünüz ne düzeydedir?" soruları ile öğrencilerden süreç içerisindeki başarılarına yönelik kendi öz değerlendirmelerini yapmaları ve eğitimcilerin öğrenci başarı düzeyine yönelik öngörü derecelerini belirtmeleri istenilmiştir. Yapılan değerlendirme sonucunda öğrencilerin "orta düzeyde" başarılı olduklarının öngörüldüğü bulgusuna ulaşılmıştır. Elde edilen veriler Tablo 3’te sunulmuştur.

Tablo 3

"Piyano eğitimi dersi başarınıza yönelik öngörünüz ne düzeydedir? - Öğrencilerinizin piyano eğitimi dersi başarılarına yönelik öngörünüz ne düzeydedir?" sorularına yönelik betimleyici tablo

\begin{tabular}{ccc|ccc}
\hline \multicolumn{2}{c|}{ Öğrenci Derecelendirmesi } & & \multicolumn{2}{c}{ Eğitimci Değerlendirmesi } \\
\hline Derecelendirme Puanı & Frekans & Yüzde & Yüzde & Frekans & \multicolumn{1}{c}{ Derecelendirme Puanı } \\
\hline 1 & 3 & 3,8 & 0,0 & 1 & 2 \\
2 & 16 & 20,3 & 14,3 & 6 & 3 \\
3 & 31 & 39,2 & 85,7 & 0 & 5 \\
4 & 17 & 21,5 & 0,0 & 0 & 5 \\
5 & 12 & 15,2 & 0,0 & $\mathbf{7}$ & Toplam \\
Toplam & $\mathbf{7 9}$ & $\mathbf{1 0 0}$ & $\mathbf{1 0 0}$ & &
\end{tabular}

“Piyano ĕğitimi dersini yürüten öğretim elemanının size karşı tutumunu nasıl değgerlendirirsiniz? - Piyano eğitimi dersini alan öğrencilerin size karşı tutumunu nasıl değerlendirirsiniz?" soruları ile süreç içerisinde öğrenci/öğretim elemanlarının tutumlarına yönelik değerlendirmelerin yapılması istenilmiştir. Yapılan değerlendirme sonucunda öğrenciler eğitimcilerinin "çok yüksek düzeyde" kendilerine olumlu tutum sergilediğini, öğrencilerin ise "yüksek düzeyde" olumlu tutum sergiledikleri bulgusuna ulaşılmıştır. Elde edilen veriler Tablo 4 'te sunulmuştur. 


\section{Tablo 4}

"Piyano eğitimi dersini yürüten öğretim elemanının size karşı tutumunu nasıl değerlendirirsiniz? - Piyano eğitimi dersini alan öğrencilerin size karşı tutumunu nasıl değerlendirirsiniz?” sorularına yönelik betimleyici tablo

\begin{tabular}{|c|c|c|c|c|c|}
\hline \multicolumn{3}{|c|}{ Öğrenci Derecelendirmesi } & \multicolumn{3}{|c|}{ Ĕgitimci Değerlendirmesi } \\
\hline Derecelendirme Puanı & Frekans & Yüzde & Yüzde & Frekans & Derecelendirme Puanı \\
\hline 1 & 2 & 2,5 & 0,0 & 0 & 1 \\
\hline 2 & 7 & 8,9 & 0,0 & 0 & 2 \\
\hline 3 & 13 & 16,5 & 0,0 & 0 & 3 \\
\hline 4 & 13 & 16,5 & 57,1 & 4 & 4 \\
\hline 5 & 44 & 55,7 & 42,9 & 3 & 5 \\
\hline Toplam & 79 & 100 & 100 & 7 & Toplam \\
\hline
\end{tabular}

“Piyano eğitimi dersine karşı tutumunuzu nasıl değerlendirirsiniz?” sorusu ile öğrencilerden ve eğitimcilerden süreç içerisinde derse karşı tutumlarını öz değerlendirmeleri istenilmiştir. Yapılan değerlendirme sonucunda "çok yüksek düzeyde" derse karşı olumlu tutum sergiledikleri bulgusuna ulaşılmıştır. Elde edilen veriler Tablo 5'te sunulmuştur.

Tablo 5

"Piyano eğitimi dersine karşı tutumunuzu nasıl değerlendirirsiniz?" sorularına yönelik betimleyici tablo

\begin{tabular}{ccc|ccc}
\hline \multicolumn{2}{c}{ Ö̆̆grenci Derecelendirmesi } & & \multicolumn{3}{c}{ Ĕ̈itimci Değerlendirmesi } \\
\hline Derecelendirme Puanı & Frekans & Yüzde & Yüzde & Frekans & Derecelendirme Puanı \\
\hline 1 & 3 & 3,8 & 0,0 & 0 & 1 \\
2 & 10 & 12,7 & 0,0 & 0 & 2 \\
3 & 25 & 31,6 & 14,3 & 1 & 3 \\
4 & 15 & 19,0 & 14,3 & 1 & 4 \\
5 & 26 & 32,9 & 71,4 & 5 & 5 \\
Toplam & $\mathbf{7 9}$ & $\mathbf{1 0 0}$ & $\mathbf{1 0 0}$ & $\mathbf{7}$ & Toplam \\
\hline
\end{tabular}

“Piyano eğitimi dersini yürü̈ten ö̆̆retim elemanının ders dıșı ilgisini nassl değerlendirirsiniz? - Piyano eğitimi dersini alan öğrencilerinize ders saati dışında yardımcı olma durumunuzu nasıl değerlendirirsiniz?" soruları ile öğrencilerden süreç içerisinde eğitmenlerinin ders dışı ilgilerine yönelik gözlemlerini belirtmeleri ve eğitmenlerin ise öz değerlendirmelerini yapmaları istenilmiştir. Yapılan değerlendirme sonucunda eğitmenlerin "yüksek düzeyde" ders dışı öğrenci ile ilgilendikleri bulgusuna ulaşılmıştır. Elde edilen veriler Tablo 6'da sunulmuştur.

Tablo 6

"Piyano eğitimi dersini yürüten öğretim elemanının ders dışı ilgisini nasıl değerlendirirsiniz? - Piyano eğitimi dersini alan öğrencilerinize ders saati dışında yardımcı olma durumunuzu nasıl değerlendirirsiniz?" sorularına yönelik betimleyici tablo

\begin{tabular}{|c|c|c|c|c|c|}
\hline \multicolumn{3}{|c|}{ Öğrenci Derecelendirmesi } & \multicolumn{3}{|c|}{ Ĕgitimci Değerlendirmesi } \\
\hline Derecelendirme Puanı & Frekans & Yüzde & Yüzde & Frekans & Derecelendirme Puanı \\
\hline 1 & 8 & 10,1 & 0,0 & 0 & 1 \\
\hline 2 & 6 & 7,6 & 14,3 & 1 & 2 \\
\hline 3 & 23 & 29,1 & 14,3 & 1 & 3 \\
\hline 4 & 12 & 15,2 & 42,9 & 3 & 4 \\
\hline 5 & 30 & 38,0 & 28,6 & 2 & 5 \\
\hline Toplam & 79 & 100 & 100 & 7 & Toplam \\
\hline
\end{tabular}

“Piyano ĕğitimi dersini ne düzeyde önemli buluyorsunuz?” sorusu ile öğrencilerden ve eğitimcilerden süreç içerisinde dersi ne kadar önemli gördüklerini değerlendirmeleri istenilmiştir. Yapılan değerlendirme sonucunda piyano eğitimi dersinin "çok yüksek düzeyde” öneme sahip olduğu bulgusuna ulaşılmıştır. Elde edilen veriler Tablo 7'de sunulmuştur.

Tablo 7

"Piyano eğitimi dersini ne düzeyde önemli buluyorsunuz?" sorusuna yönelik betimleyici tablo

\begin{tabular}{ccc|ccc}
\hline \multicolumn{2}{c|}{ Öğrenci Derecelendirmesi } & & \multicolumn{3}{c}{ Eğitimci Değerlendirmesi } \\
\hline Derecelendirme Puanı & Frekans & Yüzde & Yüzde & Frekans & Derecelendirme Puanı \\
\hline 1 & 0 & 0,0 & 0,0 & 0 & 1 \\
2 & 2 & 2,5 & 0,0 & 0 & 2 \\
3 & 16 & 20,3 & 0,0 & 0 & 4 \\
4 & 14 & 17,7 & 28,6 & 2 & 5 \\
5 & 47 & 59,5 & 71,4 & 5 & 7 \\
Toplam & $\mathbf{7 9}$ & $\mathbf{1 0 0}$ & $\mathbf{1 0 0}$ & $\mathbf{7}$ & Toplam \\
\hline
\end{tabular}

“Piyano eğitimi dersinde sunulan/sunduğunuz geri bildirimler ne düzeydir?” sorusu ile öğrencilerden ve eğitimcilerden süreç içerisinde ne kadar geri bildirim aldıklarını/verdiklerini değerlendirmeleri istenilmiştir. 
Yapılan değerlendirme sonucunda piyano eğitimi dersinde "yüksek düzeyde" geri bildirim aldıkları/sundukları bulgusuna ulaşılmıştır. Elde edilen veriler Tablo 8'de sunulmuştur.

Tablo 8

"Piyano eğitimi dersinde sunulan/sunduğunuz geri bildirimler ne düzeydir?" sorusuna yönelik betimleyici tablo

\begin{tabular}{|c|c|c|c|c|c|}
\hline \multicolumn{3}{|c|}{ Öğrenci Derecelendirmesi } & \multicolumn{3}{|c|}{ Eğitimci Değerlendirmesi } \\
\hline Derecelendirme Puanı & Frekans & Yüzde & Yüzde & Frekans & Derecelendirme Puanı \\
\hline 1 & 4 & 5,1 & 0,0 & 0 & 1 \\
\hline 2 & 9 & 11,4 & 0,0 & 0 & 2 \\
\hline 3 & 29 & 36,7 & 28,6 & 2 & 3 \\
\hline 4 & 21 & 26,6 & 28,6 & 2 & 4 \\
\hline 5 & 16 & 20,3 & 42,9 & 3 & 5 \\
\hline Toplam & 79 & 100 & 100 & 7 & Toplam \\
\hline
\end{tabular}

“Piyano ĕğitimi dersinde kullanılan/kullandı̆̆ınız yöntemlerin farklılı̆̆ı ne düzeydedir?” sorusu ile öğrencilerden ve eğitimcilerden süreç içerisinde karşılaştıkları öğrenme durumlarına göre ne kadar farklı yöntemler uygulandığını/uyguladıklarını değerlendirmeleri istenilmiştir. Yapılan değerlendirme sonucunda öğrenci görüşlerine göre piyano eğitimi dersinde "orta düzeyde" farklı yöntem sunulduğu, eğitimci görüşlerine göre ise "yüksek düzeyde" farklı yöntemler sunulduğu bulgusuna ulaşılmıştır. Elde edilen veriler Tablo 9'da sunulmuştur.

Tablo 9

"Piyano eğitimi dersinde kullanılan/kullandığınız yöntemlerin farklılığg ne düzeydedir?” sorusuna yönelik betimleyici tablo

\begin{tabular}{|c|c|c|c|c|c|}
\hline \multicolumn{3}{|c|}{ Öğrenci Derecelendirmesi } & \multicolumn{3}{|c|}{ Ĕğitimci Değerlendirmesi } \\
\hline Derecelendirme Puanı & Frekans & Yüzde & Yüzde & Frekans & Derecelendirme Puanı \\
\hline 1 & 7 & 8,9 & 0,0 & 0 & 1 \\
\hline 2 & 14 & 17,7 & 0,0 & 0 & 2 \\
\hline 3 & 26 & 32,9 & 14,3 & 1 & 3 \\
\hline 4 & 17 & 21,5 & 57,1 & 4 & 4 \\
\hline 5 & 15 & 19,0 & 28,6 & 2 & 5 \\
\hline Toplam & 79 & 100 & 100 & 7 & Toplam \\
\hline
\end{tabular}

“Piyano ĕğitimi dersine karşı motivasyonunuzun ne düzeydedir? - Piyano eğitimi dersine karşı öğrencilerin motivasyonunun ne düzeyde olduğunu düşünüyorsunuz?” soruları ile öğrencilerden ve eğitimcilerden süreç içerisinde motivasyon konusunda puanlama yapmaları istenilmiştir. Yapılan değerlendirme sonucunda öğrenci görüşlerine göre "yüksek düzeyde" derse karşı motive oldukları, eğitimci görüşlerine göre "orta düzeyde" derse karşı motive oldukları bulgusuna ulaşı1mıştır. Elde edilen veriler Tablo 10’da sunulmuştur.

Tablo 10

"Piyano eğitimi dersine karşı motivasyonunuzun ne düzeydedir? - Piyano eğitimi dersine karşı öğrencilerin motivasyonunun ne düzeyde olduğunu düşünüyorsunuz?” sorularına yönelik betimleyici tablo

\begin{tabular}{|c|c|c|c|c|c|}
\hline \multicolumn{3}{|c|}{ Öğrenci Derecelendirmesi } & \multicolumn{3}{|c|}{ Eğitimci Değerlendirmesi } \\
\hline Derecelendirme Puanı & Frekans & Yüzde & Yüzde & Frekans & Derecelendirme Puanı \\
\hline 1 & 4 & 5,1 & 0,0 & 0 & 1 \\
\hline 2 & 11 & 13,9 & 0,0 & 0 & 2 \\
\hline 3 & 19 & 24,1 & 85,7 & 6 & 3 \\
\hline 4 & 18 & 22,8 & 14,3 & 1 & 4 \\
\hline 5 & 27 & 34,2 & 0,0 & 0 & 5 \\
\hline Toplam & 79 & 100 & 100 & 7 & Toplam \\
\hline
\end{tabular}

“Piyano ĕğitimi dersini yürüten öğretim elemanının sizinle empati kurma düzeyi nedir? - Piyano eğitimi dersini alan öğrencilerinizle ne düzeyde empati kurduğunuzu düşünüyorsunuz?" sorusu ile öğrencilerden ve eğitimcilerden süreç içerisinde empati konusunda düşündüklerini derecelendirmeleri istenmiştir. Yapılan değerlendirme sonucunda "yüksek düzeyde" eğitmenin empati kurduğu bulgusuna ulaşılmıştır. Elde edilen veriler Tablo 11'de sunulmuştur.

Tablo 11

"Piyano eğitimi dersini yürüten öğretim elemanının sizinle empati kurma düzeyi nedir?” sorusuna yönelik betimleyici tablo

\begin{tabular}{|c|c|c|c|c|c|}
\hline \multicolumn{3}{|c|}{ Öğrenci Derecelendirmesi } & \multicolumn{3}{|c|}{ Ĕgitimci Değerlendirmesi } \\
\hline Derecelendirme Puanı & Frekans & Yüzde & Yüzde & Frekans & Derecelendirme Puanı \\
\hline 1 & 2 & 2,5 & 0,0 & 0 & 1 \\
\hline 2 & 4 & 5,1 & 0,0 & 0 & 2 \\
\hline 3 & 22 & 27,8 & 14,3 & 1 & 3 \\
\hline 4 & 15 & 19,0 & 71,4 & 5 & 4 \\
\hline 5 & 36 & 45,6 & 14,3 & 1 & 5 \\
\hline Toplam & 79 & 100 & 100 & 7 & Toplam \\
\hline
\end{tabular}


“Piyano ĕğitimi dersini yürüten öğretim elemanının, başarı durumunuzu değerlendirirken ne kadar adil olduğunu düşü̈n̈̈yorsunuz? - Piyano eğitimi dersini alan öğrencilerin başarı durumlarını değerlendirirken ne kadar adil olduğunuzu düşünüyorsunuz?” soruları ile öğrencilerden ve eğitimcilerden süreç içerisinde değerlendirme konusunda düşündüklerini puanlamaları istenilmiştir. Yapılan değerlendirme sonucunda öğrencilerin / eğitimcilerin "çok yüksek düzeyde" adil değerlendirildiklerini / değerlendirdiklerini gözlemledikleri bulgusuna ulaşılmıştır. Elde edilen veriler Tablo 12’de sunulmuştur.

Tablo 12

"Piyano eğitimi dersini yürüten öğretim elemanının, başarı durumunuzu değerlendirirken ne kadar adil olduğunu düşünüyorsunuz? - Piyano eğitimi dersini alan öğrencilerin başarı durumlarını değerlendirirken ne kadar adil olduğunuzu düşünüyorsunuz?" sorularına yönelik betimleyici tablo

\begin{tabular}{|c|c|c|c|c|c|}
\hline \multicolumn{3}{|c|}{ Öğrenci Derecelendirmesi } & \multicolumn{3}{|c|}{ Eğitimci Değerlendirmesi } \\
\hline Derecelendirme Puanı & Frekans & Yüzde & Yüzde & Frekans & Derecelendirme Puanı \\
\hline 1 & 1 & 1,3 & 0,0 & 0 & 1 \\
\hline 2 & 5 & 6,3 & 0,0 & 0 & 2 \\
\hline 3 & 15 & 19,0 & 0,0 & 0 & 3 \\
\hline 4 & 10 & 12,7 & 42,9 & 3 & 4 \\
\hline 5 & 48 & 60,8 & 57,1 & 4 & 5 \\
\hline Toplam & 79 & 100 & 100 & 7 & Toplam \\
\hline
\end{tabular}

\subsection{Yapılandırılmış görüşme formu bulguları}

Yapılandırılmış görüşme formunda 5 adet açık uçlu soruya yer verilmiştir. Sorulara verilen cevaplar ortak kodlamalara dönüştürülmüş ve yüzde frekans olarak ele alınmıştır.

"Piyano eğitimine yönelik ders saati içerisinde öğretim elemanından/öğrencilerden beklentileriniz nelerdir? (Bilgi aktarma/algılama, tutum/davranış, geri bildirim/dönüt, yöntem, vb.)" sorusu katılımcılara sorulmuş ve toplamda öğrenci görüşlerine göre 10 kategoride 109 kod, eğitimci görüşlerine göre 3 kategoride 15 kod elde edilmiştir. Elde edilen veriler Tablo 13’de gösterilmiştir.

Tablo 13

"Piyano eğitimine yönelik ders saati içerisinde öğretim elemanından/öğrencilerden beklentileriniz nelerdir?" sorusunu öğrenci ve eğitimci cevaplarına göre betimleyici kodlama tablosu

\begin{tabular}{|c|c|c|c|c|c|}
\hline \multicolumn{3}{|c|}{ Öğrenci Görüşleri } & \multicolumn{3}{|c|}{ Eăitimci Görüsleri } \\
\hline $\begin{array}{c}\text { Belirlenen Beklenti } \\
\text { Kodları }\end{array}$ & Frekans & Yüzde & Yüzde & Frekans & $\begin{array}{c}\text { Belirlenen Beklenti } \\
\text { Kodları }\end{array}$ \\
\hline Bilgi Aktarma & 22 & 20,2 & 40,0 & 6 & Hazırbulunuşluk \\
\hline Olumlu Tutum/Davranıș & 11 & 10,1 & 26,7 & 4 & Bilgiyi Algilama \\
\hline Geri Bildirim & 3 & 2,8 & 33,3 & 5 & Geri Dönüt \\
\hline Farklı Yöntemlerin & 23 & 21,1 & & & \\
\hline İlgi & 14 & 12,8 & & & \\
\hline İletişim & 3 & 2,8 & & & \\
\hline Eğitimci Kalitesi & 1 & 0,9 & & & \\
\hline Bireysel Farkl11ıkların & 4 & 3,7 & & & \\
\hline $\begin{array}{l}\text { Gözetilmesi } \\
\text { Empati }\end{array}$ & 1 & 0.9 & & & \\
\hline Mevcut Durumdan & & & & & \\
\hline Memnun Olma & 27 & 24,8 & & & \\
\hline Toplam & 109 & 100 & 100 & 15 & Toplam \\
\hline
\end{tabular}

"Piyano eğitimine yönelik ders saati dışında öğretim elemanından/öğrencilerden beklentileriniz nelerdir? (Bilgi aktarma/tekrarlama, tutum/davranış, rehberlik, geri bildirim/dönüt, vb.)" sorusu katılımcılara sorulmuş ve toplamda öğrenci görüşlerine göre 10 kategoride 96 kod, eğitimci görüşlerine göre 5 kategoride 19 kod elde edilmiştir. Elde edilen veriler Tablo 14'te gösterilmiştir.

Tablo 14

"Piyano eğitimine yönelik ders saati dışında öğretim elemanından/öğrencilerden beklentileriniz nelerdir?" sorusuna yönelik betimleyici tablo

\begin{tabular}{ccc|ccc}
\hline \multicolumn{1}{c}{ Öğrenci Görüșleri } & & \multicolumn{2}{c}{ Ĕgitimci Görüşleri } \\
\hline $\begin{array}{c}\text { Belirlenen Beklenti } \\
\text { Kodları }\end{array}$ & Frekans & Yüzde & Yüzde & Frekans & $\begin{array}{c}\text { Belirlenen Beklenti } \\
\text { Kodları }\end{array}$ \\
\hline Bilgi Aktarma & 22 & 22,9 & 26,3 & 5 & Geri Dönüt \\
Olumlu Tutum/Davranış & 7 & 7,3 & 31,6 & 6 & Bilgiyi Tekrarlama \\
Rehberlik & 14 & 14,6 & 5,3 & 3 & Hazırbulunuşluk \\
Geri Bildirim & 7 & 7,3 & 15,8 & 4 & Dinleme \\
İlgi & 11 & 11,5 & 21,1 & & Bilgi Edinme \\
Farklı Yöntemlerin & 1 & 1,0 & & & \\
Uygulanması & & & & \\
\hline
\end{tabular}


Tablo 14’ün devamı

\begin{tabular}{|c|c|c|c|c|c|}
\hline \multicolumn{3}{|c|}{ Öğrenci Görüșleri } & \multicolumn{3}{|c|}{ Eğitimci Görüșleri } \\
\hline $\begin{array}{c}\text { Belirlenen Beklenti } \\
\text { Kodları }\end{array}$ & Frekans & Yüzde & Yüzde & Frekans & $\begin{array}{c}\text { Belirlenen } \\
\text { Beklenti Kodları }\end{array}$ \\
\hline Empati & 1 & 1,0 & & & \\
\hline Güdüleme & 1 & 1,0 & & & \\
\hline Ulaşılabilirlik & 2 & 2,1 & & & \\
\hline $\begin{array}{l}\text { Mevcut Durumdan } \\
\text { Memnun Olma }\end{array}$ & 30 & 31,3 & & & \\
\hline Toplam & 96 & 100 & 100 & 19 & Toplam \\
\hline
\end{tabular}

“Piyano eğitimi dersine yönelik motivasyonun artması için ne tür çalışmalar yapılmasını bekliyorsunuz?" sorusu katılımcılara sorulmuş ve toplamda öğrenci görüşlerine göre 10 kategoride 93 kod, eğitimci görüşlerine göre 3 kategoride 15 kod elde edilmiştir. Elde edilen veriler Tablo 15’te gösterilmiştir.

Tablo 15

"Piyano eğitimi dersine yönelik motivasyonun artması için ne tür çalışmalar yapılmasını bekliyorsunuz?” sorusuna yönelik betimleyici tablo

\begin{tabular}{|c|c|c|c|c|c|}
\hline \multicolumn{3}{|c|}{ Öğrenci Görüşleri } & \multicolumn{3}{|c|}{ Eğitimci Görüşleri } \\
\hline $\begin{array}{l}\text { Belirlenen Beklenti } \\
\text { Kodları }\end{array}$ & Frekans & Yüzde & Yüzde & Frekans & $\begin{array}{c}\text { Belirlenen Beklenti } \\
\text { Kodları }\end{array}$ \\
\hline Etkinlik & 11 & 11,8 & 33,3 & 5 & Dinleme \\
\hline Piyano Sayısı & 9 & 9,7 & 40,0 & 6 & Güdülenme \\
\hline İletişim & 1 & 1,1 & 26,7 & 4 & Etkinlik \\
\hline İlgi & 6 & 6,5 & & & \\
\hline Ders Saati Sayı1s1 & 9 & 9,7 & & & \\
\hline Farklı Yöntemlerin & 21 & 22.6 & & & \\
\hline Uygulanması & & & & & \\
\hline Aynı Saatte Derse Giren & 4 & 4,3 & & & \\
\hline $\begin{array}{l}\text { Öğrenci Sayıs1 } \\
\text { Güdüleme }\end{array}$ & 4 & 43 & & & \\
\hline $\begin{array}{l}\text { Guduleme } \\
\text { Bireysel Farklılıkların }\end{array}$ & & & & & \\
\hline Gözetilmesi & 14 & 15,1 & & & \\
\hline Mevcut Durumdan & 14 & 15,1 & & & \\
\hline $\begin{array}{l}\text { Memnun Olma } \\
\text { Toplam }\end{array}$ & 93 & 100 & 100 & 15 & Toplam \\
\hline
\end{tabular}

“Piyano eğitimi dersine yönelik sınav değerlendirmenizin nasıl yapılmasını bekliyorsunuz? - Piyano eğitimi dersini değerlendirme aşamasında öğrencilerinizden beklentileriniz neler?" soruları katılımcılara sorulmuş ve toplamda öğrenci görüşlerine göre 5 kategoride 90 kod, eğitimci görüşlerine göre 3 kategoride 15 kod elde edilmiştir. Elde edilen veriler Tablo 16'da gösterilmiştir.

Tablo 16

"Piyano eğitimi dersine yönelik sınav değerlendirmenizin nasıl yapılmasını bekliyorsunuz? - Piyano eğitimi dersini değerlendirme aşamasında öğrencilerinizden beklentileriniz neler?” sorularına yönelik betimleyici tablo

\begin{tabular}{|c|c|c|c|c|c|}
\hline \multicolumn{3}{|c|}{ Öğrenci Görüşleri } & \multicolumn{3}{|c|}{ Eğitimci Görüșleri } \\
\hline $\begin{array}{c}\text { Belirlenen Beklenti } \\
\text { Kodları }\end{array}$ & Frekans & Yüzde & Yüzde & Frekans & $\begin{array}{c}\text { Belirlenen Beklenti } \\
\text { Kodları }\end{array}$ \\
\hline Değerlendirme Yöntemi & 42 & 46,7 & 46,7 & 7 & Hazırbulunuşluk \\
\hline Adil Değerlendirme & 14 & 15,6 & 26,7 & 4 & Geri Dönüt \\
\hline $\begin{array}{c}\text { Bireysel Farklılı̆̆ın } \\
\text { Gözetilmesi }\end{array}$ & 10 & 11,1 & 26,7 & 4 & Ders Durumu \\
\hline Empati & 1 & 1,1 & & & \\
\hline $\begin{array}{l}\text { Mevcut Durumdan } \\
\text { Memnun Olma }\end{array}$ & 23 & 25,6 & & & \\
\hline Toplam & 90 & 100 & 100 & 15 & Toplam \\
\hline
\end{tabular}

“Genel anlamda piyano eğitimi dersini değerlendirecek olursanız, yukarıdaki sorulara eklemek istediğiniz beklentileriniz nelerdir?" sorusu katılımcılara sorulmuş ve toplamda öğrenci görüşlerine göre 9 kategoride 86 kod, eğitimci görüşlerine göre 5 kategoride 14 kod elde edilmiştir. Elde edilen veriler Tablo 17'de gösterilmiştir.

Tablo 17

"Genel anlamda piyano eğitimi dersini değerlendirecek olursanız, yukarıdaki sorulara eklemek istediğiniz beklentileriniz nelerdir?" sorusuna yönelik betimleyici tablo

\begin{tabular}{ccc|ccc}
\hline \multicolumn{2}{c}{ Öğrenci Görüşleri } & & \multicolumn{2}{c}{ Eğitimci Görüşleri } \\
\hline $\begin{array}{c}\text { Belirlenen Beklenti } \\
\text { Kodları }\end{array}$ & Frekans & Yüzde & Yüzde & Frekans & $\begin{array}{c}\text { Belirlenen Beklenti } \\
\text { Kodları }\end{array}$ \\
\hline Ders Saati Sayısı & 14 & 16,3 & 21,4 & 3 & Eğitimci Sayıs1 \\
Eğitim Kalitesi & 2 & 2,3 & 14,3 & 2 & Piyano Sayıs1 \\
\hline
\end{tabular}


Tablo 17'nin devamı

\begin{tabular}{|c|c|c|c|c|c|}
\hline \multicolumn{3}{|c|}{ Öğrenci Görüșleri } & \multicolumn{3}{|c|}{ Eğitimci Görüşleri } \\
\hline $\begin{array}{c}\text { Belirlenen Beklenti } \\
\text { Kodları }\end{array}$ & Frekans & Yüzde & Yüzde & Frekans & $\begin{array}{c}\text { Belirlenen Beklenti } \\
\text { Kodları }\end{array}$ \\
\hline Piyano Sayısı & 7 & 8,1 & 35,7 & 5 & Ders Saati Sayısı \\
\hline Eğitimci Sayısı & 1 & 1,2 & 14,3 & 2 & Ders Dönemi Sayısı \\
\hline Ders Dönemi Sayısı & 7 & 8,1 & 14,3 & 2 & Ders Devamı \\
\hline Empati & 1 & 1,2 & & & \\
\hline $\begin{array}{c}\text { Aynı Saatte Derse Giren } \\
\text { Öğrenci Sayısı }\end{array}$ & 2 & 2,3 & & & \\
\hline Etkinlik & 3 & 3,5 & & & \\
\hline $\begin{array}{l}\text { Eklenmek İstenen } \\
\text { Beklenti Yok }\end{array}$ & 49 & 57,0 & & & \\
\hline Toplam & 86 & 100 & 100 & 14 & Toplam \\
\hline
\end{tabular}

\section{Sonuçlar ve öneriler}

Elde edilen bulgular 1şı̆̆ın sonuçlar her soru için ayrı ayrı ve form bazında genel olarak ele alınmıştır.

1. Katılımcılar arasındaki homojenliğin sağlanıp sağlanmadığı test edilmiş ve katılımcılar arasında bir farklılığın olmadığı, bu sonuca istinaden çalışma grubundan elde edilen verilerin mevcut durumu yansıttı̆̆ varsayilmaktadır.

2. Piyano eğitimi dersine öğrencilerin ne kadar çalıştıklarına ilişkin bulgular incelendiğinde, hem öğrencilerin hem de eğitimcilerin, öğrencilerin derse yönelik çalışmalarının orta düzeyde olduğunu gözlemledikleri, bu sebeple piyano eğitimi dersini alan öğrencilere çalışma disiplini kazandırılması için gereken güdülemelerin yapılması gerektiği söylenebilir.

3. Piyano dersi başarısına yönelik öğrenci ve eğitimcilerden elde edilen bulgulara istinaden, hem öğrencilerin hem de eğitimcilerin, derse yönelik öğrenci başarısının orta düzeyde olduğunu gözlemledikleri, bu sebeple piyano eğitimi sürecinde kalitenin/başarının artırılması için çalışmalar yapılması gerektiği söylenebilir.

4. Eğitimci ve öğrencilerin ders sürecinde birbirlerine karşı tutum ve davranışlarına yönelik elde edilen bulgulara istinaden, birbirlerine yüksek düzeyde olumlu tutum/davranış sergiledikleri, bu sebeple ders sürecini olumsuz etkiyebilecek etkenlerden birinin gözlemlenmediği söylenebilir.

5. Hem eğitimcilerin hem de öğrencilerin piyano eğitimi dersine yönelik yüksek düzeyde olumlu tutum sergiledikleri söylenebilir.

6. Katılımcıların ders saati dışındaki etkileşimlerinin ne düzeyde olduğu araştırılmak istenilmiş ve elde edilen bulgulara göre yüksek düzeyde etkileşim olduğu sonucuna varılmıştır.

7. Piyano eğitiminin öğrenciler ve eğitimciler tarafından genel olarak çok yüksek düzeyde önemli olduğu söylenmiştir. Düşük veya orta derecelendirmelerde bulunan katılımcıların (yaklaşık olarak katılımcıların 1/4 ü) ders süreci içerisindeki öngördükleri önem düzeydeki artışın sağlanması için motivasyonlarının ve beklentilerinin karşılanması gerektiği söylenebilir.

8. Piyano eğitimi sürecinde ders ile ilgili gerçekleştirilen bir davranışa sunulan geri bildirim seviyesinin öğrenci görüşlerine göre orta düzeyde, eğitimci görüşlerine göre yüksek düzeyde olduğu görülmüştür. Bu sonuca istinaden sonuçlar arasındaki farkın eşitlenmesi adına, sunulan geri bildirimlerin doğru algılanması için farklı yöntemler kullanılarak sunulması veya geri bildirimin tekrarlanması gerektiği söylenebilir.

9. Piyano eğitimi sürecinde uygulanan yöntem ve tekniklerin çeşitliliğinin ortaya konulması amacıyla elde edilen bulgulara istinaden, öğrenci görüşlerine göre orta düzeyde, eğitimci görüşlerine göre ise yüksek düzeyde farklı yöntem kullanıldığı sonuçları elde edilmiştir. Eğitim sürecinde farklı yöntemler kullanılsa dahi öğrenciler arasındaki bireysel farklılıklar gözetilerek yöntemlerle birlikte kullanılan ders materyallerinde ki çeşitliliğin de artırılması gerektiği söylenebilir.

10. Piyano eğitimi sürecinde öğrenci motivasyonlarının öğrenci görüşlerine göre yüksek düzeyde, eğitimci görüşlerine göre orta düzeyde olduğu görülmüştür.

11. Piyano eğitimi sürecinde katılımcıların birbirlerine karşı yüksek düzeyde empati sağladıkları söylenebilir.

12. Eğitim sürecinin değerlendirilmesi aşamasında çok yüksek düzeyde adil değerlendirmenin yapıldığı söylenebilir.

13. Ders içi beklentiler için hazırlanan görüşme formu sorusuna istinaden, öğrencilerin yaklaşık olarak, $1 / 4$ ünün mevcut durumdan memnun oldukları, 1/4 ünün daha fazla bilgi aktarımı yapılmasını istediği, 1/4 ünün daha iyi algılayacaklarını belirterek kendilerine yönelik farklı yöntemler kullanılmasını istedikleri, 1/4 ünün 
kendilerine daha fazla ilgi gösterilmesi/zaman ayırılması gerektiğini düşündükleri sonuçlarına varılmıştır. Buna karşlık olarak eğitimcilerin öğrencilerden, dersle ilgili hazırbulunuşluklarını artırmaları gerektiği, doğru algıladıklarını bildikleri bilgileri işleyebilmeleri ve ders sürecinde verilen bilgiyi algılayabilmeleri için derste ilgili davranmaları gerektiği sonuçlarına varılmıştır. Bu sonuçlar ışığında; karşılıklı olarak beklentiler incelendiğinde öğrencilerin derse çalışma durumları ve ders başarılarının orta düzeyde olduğu göz önüne alınarak, dersin kalitesinin artırılması için öncelikle öğrencide ki motivasyon sürecinin doğru işlenmesi ile istenilen davranış değişikliğinin elde edilmesi gerektiği görülmektedir.

Görüşme formunda sunulan soru için verilen bazı cevaplar aşağıdaki gibidir;

Örnek olarak; Katılımcı 19: Derse gruplar halinde giriyoruz. Bu sebeple öğrenciler seviyesine göre gruplara ayrılıp, seviyelere göre dersin işlenmesini bekliyorum.

Katılımcı 22: Hocanın anlatımıyla benim anlamam aynı değil.

Katılımc 29: Piyanoyu sevdirmesi, dersi daha eğlenceli anlatması.

Katılımc 34: Daha fazla ödevlendirmesi.

Katılımc1 51: Derslerde daha sicak davranması.

Katılımc1 53: Düz lise çıkışlı bir öğrenci olarak piyano eğitiminin en başından öğretilmesi gerektiğini düşünüyorum, Sınav eseri vererek sadece onları çalmam beklenmemeli.

Katılımcı 64: Eseri çalması.

Eğitimci 1: Deşifresi tam bir şekilde gelmesini bekliyorum. Ancak birçok öğrenci çalışmadan geliyor ve parmaklarıma bakarak ezber yapmaya çalışıyor.

Eğitimci 2: Derste bilgiyi algılayamıyor çünkü dikkatleri çok dağınık.

Eğitimci 4: Bir önceki ders verilen ve istenilen ödev ile ilgili beklentilerimi karşılamalarını, o derste çalışılacak eser, etüt vb. çalışmalara hazırbulunuşluk bakımından yeterli gelmelerini bekliyorum.

Verilen örnek söylemler incelendiğinde eğitimci ve öğrencilerin birbirlerine karşı beklentileri farklılık göstermemektedir. Eğitimcinin bireysel farklılı̆̆ gözetmesi, öğrenciye zaman ayırması, doğru pekiştirmelerle öğrenciyi güdülemesi ile eğitim kalitesinde artış yaşanabileceği öngörülmektedir. Ancak bazı öğrencilerin derse karșı olumsuz tutumları devam edebileceğinden dersin mutlak bașarıya ulaşması söz konusu değildir.

14. Ders dışı beklentiler için hazırlanan görüşme formu sorusuna istinaden, derecelendirme formunda ders dişı etkileșimin yüksek düzeyde olduğu ortaya konulmasına rağmen, Öğrencilerin $1 / 3$ nün mevcut durumdan memnun olduğu, $1 / 3$ nün ek bilgi talebinde bulunduğu ve $1 / 3$ nün rehberlik hizmeti ve daha fazla ilgi beklentisi içerisinde oldukları sonuçlarına varılmıştır. Öğrenci görüşlerine karşılık olarak eğitimciler ise her müzik alanı dersinin gerektirdiği gibi öğrencilerden öğrendikleri bilgiyi tekrar etmelerini, eserleri dinlemelerini, müzik alanında ek bilgiler edinmelerini ve tekrarladıkları-öğrendikleri her bilgi için geri dönütte bulunmalarını beklemektedir.

Görüşme formunda sunulan soru için verilen bazı cevaplar aşağıdaki gibidir;

Örnek olarak; Katılımcı 66: Sürekli yapamadığın yer var mı? Diye sorması kontrol etmesini bekliyorum.

Katılımcı 79: Hocalar çalışma odalarına gelip ilerleme var mı diye kontrol etmelerini bekliyorum. Tabii bizimde azimle çalışmamız gerekli.

Katılımcı 36: Bana iyi bir piyanist olacă̆ımı, gayret etmem gerektiğini söyleyerek özgüvenimi artırması.

Katılımcı 41: Yol gösterici olması ve arkadaş gibi davranmasını istiyorum.

Eğitimci 1: Bol bol tekrar etmelerini bekliyorum.

Eğitimci 2: Doğru parmaklarla ve yavaş tempoda düzenli olarak tekrar yapmaları.

Eğitimci 3: Çalıștığı eserin bestecisi, dönem özellikleri ve eser hakkında genel bilgi edinmesini, bestecinin diğer eserlerini de dinleyerek müzikal olarak özümsemesini beklerim.

Verilen örnek söylemler incelendiğinden eğitimciler her derste yapıldığı gibi doğru çalışma becerilerinin uygulanarak derse hazırlık yapılmasını beklemektedir. Öğrenciler ise derse hazırlık sürecinde dahi eğitimci desteği ve ilgisi beklemektedir. Eğitmenlerin ders saati dışında zaten ilgili oldukları birçok öğrenci görüşünde yer aldığı göz önünde bulundurularak, ders dışı süreçteki kalite artışının sağlanması için eğitimcilerin, akran 
eğitimi gibi farklı çalışma yöntemlerini öğrencilerine aşılamaları ve öğrencilere "nasıl araştırma yapacağı" konusunda ön bilgiler vermesi gerektiği öngörülmektedir.

15. Piyano Eğitimi dersine yönelik motivasyon durumunda artışın sağlanması için hazırlanan görüşme formu sorusuna istinaden, öğrencilerin birçoğu daha eğlenceli yöntemler kullanılarak desin işlenmesi, etkinlik sayılarının artırılarak öğrencilerinde bu etkinliklere dahil edilmesi, çalışma odası ve piyano sayılarının artırılması ile daha çok çalışma ortamı yaratılması ve ders saati artışı ile öğretmenle daha fazla vakit geçirmelerinin motivasyonlarını artıracağ yönünde görüşler elde edilmiştir. Buna karşılık olarak eğitimcilerde, güdülenmeye açık olan öğrencilere doğru pekiştireçler verildiği sürece motivasyonun artacağı, etkinlik sayısının artması gerektiği fakat öğrenci hazırbulunuşluklarının buna yeterli olmaması sebebiyle dinleme yaparak bu açıklarını kapatmaları gerektiği beklentileri içerisinde olduklarını belirtmişlerdir.

Görüşme formunda sunulan soru için verilen bazı cevaplar aşağıdaki gibidir;

Örnek olarak; Katılımcı 21: Hocamla birlikte 4 el eser çalmak güzel olabilir ve motivasyonumu artırır.

Katılımcı 18: Gerekli zamanlarda grup çalışması yapılabilir.

Katılımc1 66: Sevdiğimiz eserlerin verilerek motivasyonumuz artırılabilir.

Katılımc1 37: Daha çok destek ve övgü.

Katılımcı 36: Daha fazla piyanoyla öğrenciler kendini gerçekleştirebilir. Eğlenceli programlar yapılabilir.

Katılımcı 54: Piyano dersini ilk defa aldığım için diğerleri ile kıyaslanmamam gerektiğini düşünüyorum. Diğer arkadaşlarımın ileri seviyede olduğunu görünce ve benimle derse girdikleri zaman motivasyonum düşüyor.

Eğitimci 4: Seviyesine uygun sevdiği eserleri ödevlendiriyorum, çalgıyla daha çok bağ kurmaları içinse bolca dinleme yapmalarını bekliyorum.

Eğitimci 6: Sosyal sorumluluk projeleri üretilerek öğrencilerin desteği ile öğrendikleri çalgıyı öğretmeleri sağlanabilir. Öğretme duygusu yaşayan öğrenciler eğitimcilikteki süreçleri de gördükleri için daha çok kendilerini güdüleyebilecekleri kanaatindeyim.

Ĕ̆itimci 7: Öğrencilerimin motivasyonunu artırmak için elimden geleni yaptığımı düşünüyorum. Sevdikleri eserleri veriyorum, birlikte seslendirmeler yapıyorum. Öğrencilerimin hazırbulunuşlukları etkinlik yapacak seviyede olmadığı için grup çalışmalarına ve internet üzerinden sunulmuş olan videolara yönlendiriyorum. Fakat motivasyonlarını artırmak için yaptığım bu kadar uğraşa rağmen geri dönüt alamadığı görüyorum. Öğrencilerin birazda kendilerini güdülemelerini bekliyorum.

Verilen örnek söylemler incelendiğinde, ders içi ve dışı süreç içerisinde eğitimcilerin birçok öğrenciyi motive ettikleri ve motivasyonu düşük olan öğrenciler için ise çeşitli güdülemelerde bulundukları görülmüştür. Motivasyonunun düşük olduğu belirlenen öğrencilerle görüş̧meler yapılarak mevcut durum içerisindeki sorunların giderilmesi öğrenci motivasyonunda artış sağlayacağı öngörülmektedir.

16. Piyano Eğitimi dersinin değerlendirilmesi aşamasında hazırlanan görüşme formu sorusuna istinaden, öğrencilerin çok yüksek düzeyde adil değerlendirildikleri göz önünde bulundurularak, değerlendirme yöntemi kategorisinde öğrencilerin yoğunlaştığı görülmektedir. Öğrenciler değerlendirme yöntemi kategorisinde; sınavın yapıldığı ortam, ders içi durumlarının gözetilerek heyecan faktörünün farkında olunması ve sınavların komisyonca yapılmaması beklentilerinde bulundukları görülmektedir. Ek olarak mevcut durumdan memnun olan öğrenci sayısı da azımsanmayacak düzeyde olduğu görülmektedir. Eğitimciler ise, öğrencilerin değerlendirme aşaması için yaptıkları çalışmanın yeterli olmadığını dile getirmişlerdir. İki grup arasındaki beklentiler incelendiğinde, öğrencilerin derse çalışma durumları ve başarılarındaki öz değerlendirmelerinin orta düzeyde olduğu göz önünde bulundurulduğunda, eğitimcilerin öğrencilerden değerlendirme aşamasındaki beklentileri daha anlamlı olduğu söylenebilir. Bu sebeple öğrencilere değerlendirme puanlaması içerisindeki her bölümün açıkça anlatılması ve değerlendirme aşamasının mevcut durumunun devam etmesi gerektĭgindeki önem açıklanarak teşvik edilmesi gerektiği düşünülmektedir.

Görüşme formunda sunulan soru için verilen bazı cevaplar aşağıdaki gibidir;

Örnek olarak; Katılımcı 52: Öğrenciye derste verilen eğitime göre ve öğrencinin seviyesine göre sınav değerlendirilmesi yapılması gerekli ve sınav anındaki heyecanımız göz önüne alınarak puan verilmesi gerek. Ders içi tutum göz önünde bulundurulmalı.

Katılımc1 60: Komisyon olmaması daha iyi olur. Öğrencilerin heyecanlanmasından dolayı not düșürülmemesi lazım. 
Katılımcı 40: Farklı kişiler yanında performansımı sergileyemiyorum. Çok heyecan yapıyorum ve bu performansıma yansıyor. Kötü çalışıyorum. Bu huyumdan kurtulmak istiyorum. Bunun içinde sınavlarda komisyon olması taraftarıyım.

Katılımcı 22: Bilen ile bilmeyenin ayırt edilmesi için aynı eserler verilmeli.

Eğitimci 1: Tam olarak hazır bir şekilde gelmeleri gerekmesine rağmen genelde bahanelerle karşılaşıyorum

Eğitimci 3: Derse düzenli katılım, ödevlerin zamanında gelmesi, derste yapılan çalışmaların özümsenip eser ve etütlerde doğru uygulanmasını bekliyorum.

Değerlendirme aşamasında Bergee, Martin J. (2003), yaptığı araştırmada dönem sonu uygulamalı müzik performanslarında gözlemciler arası uyumun sağlanarak güvenilirliğinin ortaya konulması gerektiği ve bu kapsamda değerlendirmede en az beş hakemin bulunması önerisinde bulunmuştur (Akt. Çoban, 2011). Bu sebeple sınavların güvenilirliği açısından komisyon sınavlarının gerekliliği ortaya konulmaktadır. Değerlendirme aşamasında eğitimcilerin sunduğu görüşler incelendiğinde, öğrencilerin hazırbulunuşluklarının yükselmesi ile sınav kaygılarında azalma olacağı ve komisyon ile değerlendirme sırasında performanslarında daha az düşüş sağlanacağı görülmektedir. Ek olarak, öğrencilerde ki kaygının azaltılması adına çalışmalar yapılması da mevcut durumun iyileşmesi adına yardımcı olacağı yapılan çalışmalarla da bildirilmiştir (Bergee, Martin J. 2003; Çoban S. 2011; Alpagut U. 2004; Nalbantoğlu, 2007, Yöndem, Y. D. 2012).

17. Hazırlanan görüşme formundaki sorulara ek olarak belirtilmek istenilen beklentilere ilişkin sorulan soruya istinaden, öğrencilerin büyük çoğunluğu ek yapmamış, geriye kalan öğrencilerin bir kısmının ders saatinin yetersizliğinden bahsetmiştir. Ek olarak öğrencilerin çalışma odası ve piyano sayısında artış beklediği görülmektedir. Eğitimciler ise, Ders saati sayısına vurgu yapmışlardır. Bunun yanı sıra ders saatinde artış yaşanamayacağını göz önünde bulunduran eğitimciler derslerin mevcut yapı içerisinde verimli yürütülmesi adına eğitimci sayısında artış olması beklentisi içerisinde oldukları görülmüştür.

Görüşme formunda sunulan soru için verilen bazı cevaplar aşağıdaki gibidir;

Örnek olarak; Katılımcı 45: Ders saatinin artırılması gerek.

Katılımc 44: Piyano dersi bir yıldan fazla olmalı.

Katılımcı 23: Sadece piyano sayısının artırılmasını istiyorum.

Eğitimci 1: Daha çok imkân, hoca, çalışma odası ve piyano. İmkânlar arttıkça sorunların düzeleceğini düşünüyorum.

Eğitimci 2: Ders süresi az olduğu için daha çok etüt, eser ve teknik verilmeli ve öğrencilerden ise bu süreçte daha çok çalışmalarını bekliyorum.

Eğitimci 3: Günümüzde piyano ders saatleri ve toplam öğrenci sayısına göre piyano öğretmeni eksikliği nedeniyle haftada öğrencilere düşen piyano ders saatlerinin kısıtlı olması öğrencilerden beklentimizi düşürmektedir.

Verilen örnek söylemler incelendiğinde, öğrencilerin büyük çoğunluğunun ders saati artışı konusunda yorum bildirmeği de göz önünde bulundurularak, mevcut durum içerisinde ders saati sayısının artışı konusundaki beklenti, imkanların artırılması ile çözülebileceği öngörülmektedir.

Genel anlamda yapılan çalışma değerlendirilecek olunursa, öğrencilerin beklenti içerisinde oldukları konular olduğu ve bu konuların imkanlar dahilinde çözüme kavuşabileceği, eğitimcilerin beklentileri konusunda da yine eğitimciler tarafından öğrenciler desteklenerek çözüme kavuşabileceği ve piyano eğitimindeki kalitenin artırılması için öğrenci ve eğitimcilerin çabalarının önemli olduğu söylenebilir. Ayrıca yapılan çalıșmanın mevcut durumun bir öngörüsü olarak ele alınması gerektiği söylenebilir.

\section{Kaynakça}

Alpagut, U. (2004) Keman Eğitiminde Kurul Önünde Gerçekleşen Sınavlarda Değerlendirmede Standardizasyon. 1924-2004 Musiki Muallim Mektebinden Günümüze Müzik Öğretmeni Yetiştirme Sempozyumu. SDÜ, 7-10 Nisan 2004, Isparta.

Anık, C. (2007). Eğiticinin performansını niteleyen faktörler. Bilig, Güz sayı 43, s. 133-168.

Çevik, D. B., Perkmen, S. \& Alkan, M. (2012). Müzik öğretmeni adaylarının mesleklerinden beklentileri. Ĕgitim ve Öğretim Dergisi, 1,1 s. 41-45. 
Çoban, S. (2011). Müzik öğretmeni adaylarının bireysel çalgı eğitimi dersi dönem sonu sınavların ile ilgili düşünceleri (Marmara Üniversitesi Örneği). Buca Ĕgitim Fakültesi Dergisi, 31, s. 115-127.

Ekinci, C. E., \& Burgaz, B. (2007). Hacettepe Üniversitesi öğrencilerinin bazı akademik hizmetlere ilişkin beklenti ve memnuniyet düzeyleri. Hacettepe Üniversitesi Eğitim Fakültesi Dergisi, 33, 120-134. Erişim adresi: http://efdergi.hacettepe.edu.tr/yonetim/icerik/makaleler/1016-published.pdf

Erdem, A. R. (1998). Süreç kuramlarının eğitim yönetimine katkıları. Pamukkale Üniversitesi Ĕ̆itim Fakültesi Dergisi, 4, s. 51-57.

Hampton, D. R., Summer, C. E., \& Webber, R. A. (1982). Organizational behavior and the practice of management. California: Scott-Foresman.

Nalbantoğlu, E. (2007). Yaylı çalgılar öğrencilerinin performansını etkileyen bazı faktörler ve ölçme değerlendirme yöntemleri üzerine bir araştırma (Doktora tezi). YÖK Tez veri tabanından erişildi. (Tez No. 210297)

Saydan, R. (2008). Üniversite öğrencilerinin öğretim elemanlarından kalite beklentileri: Yüzüncü Yıl Üniversitesi İIBF örneği. Gazi Üniversitesi Iktisadi ve İdari Bilimler Fakültesi Dergisi 10,1. s. 62-79.

Steers, R. M., \& Porter, L. W. (1987). Motivation and work behavior. New York: McGraw-Hill.

Yöndem, Z. D. (2012). Müzik Öğrencilerinde algılanan performans kaygısının fiziksel, davranışsal ve bilişsel özellikleri: nitel bir çalışma. Eğitim ve Bilim Dergisi, 37, 167, s. 181-194. 